\title{
ZNF331 wt Allele
}

National Cancer Institute

\section{Source}

National Cancer Institute. ZNF331 wt Allele. NCI Thesaurus. Code C97880.

Human ZNF331 wild-type allele is located in the vicinity of 19q13.42 and is approximately $59 \mathrm{~kb}$ in length. This allele, which encodes zinc finger protein 331, is involved in the regulation of transcription. Chromosomal rearrangement affecting this gene is associated with follicular adenoma of the thyroid gland. 